(Received October 2, 1980)

\title{
A MECHANISM OF ADSORPTION OF HYDROGEN IONS ON SILK STUDIED BY ACID-BASE EQUILIBRIUM OF AN OPTICAL PROBE CONJUGATE*
}

\author{
By Nobuo Ikuta, Eisaku Nomura, Joichi Koga and Nobuhiko Kuroki \\ (Department of Applied Chemistry, University of Osaka Prefecture, \\ Mozu-Umemachi, Sakai, Osaka, 591)
}

\begin{abstract}
The acid-base equilibrium of an optical probe, 5-dimethylamino-1-naphthalenesulfonyl group, conjugated to silk fiber was investigated by fluorescence measurements in water and in $0.1 \mathrm{M} \mathrm{NaCl}$ solution. The apparent $\mathrm{p} K$ values of the conjugated probe were smaller than that of the free probe in the aqueous solution and decreased with decreasing $\mathrm{pH}$. The results were interpreted by considering the chemical potential of hydrogen ion and the electrical potential of the fiber phase in GilbertRideal and Peters-Speakman theories. On the other hand, the affinity of hydrogen ion for silk fiber was determined from the adsorption experiments. It was suggested from the comparison of the affinity with the $\mathrm{p} K$ value of the conjugated probe that the activity coefficient of hydrogen ion in the fiber phase was reduced to $c a_{0} 80 \%$ of the coefficient in the aqueous solution.
\end{abstract}

\section{INTRODUCTION}

In a previous paper'), we investigated the acidbase equilibrium of an optical probe, 5-dimethylamino-1-naphthalenesulfonyl group (DNS), conjugated to nylon 6 film. In the investigation, the DNS conjugate was found to be useful for studying the acid-base equilibria in the polyamide and protein fibers to provide significant informations about the mechanism of the acid dyeing. The behavior of the acid-base equilibria of the DNS conjugate suggested the presence of the electrical potential difference between the fiber phase and the external solution. In the course of the acid dyeing, the potential should contribute to distribution equilibria of all ion species, such as hydrogen ion, inorganic ions, and dye ions, between the two phases. Therefore, the potential should be incorporated in the mechanistic consideration of the acid dyeing.

In the basic investigations for the acid dyeing, the adsorption of hydrochloric acid on the fibers of wool $^{2)}$, silk ${ }^{3)}$, and nylons ${ }^{4,5)}$ has thermodynamically been treated by the two theoretical expressions proposed by Gilbert and Rideal ${ }^{2}$, and Peters and Speakman ${ }^{2}$. However, in their ex-

\footnotetext{
* "Acid-Base Equilibria of Dissociative Groups in Protein and Polyamide Fibers (Part II)"
}

pressions the term related to the electrochemical potential was not included.

In the present paper, we reconsider the adsorption of hydrochloric acid on fibers from the viewpoint of the acid-base equilibria of the dissociative groups in the fibers, and attempt to obtain an expression including the electrical potential term. In this study the acid-base equilibrium of DNS conjugated to silk is discussed by the expression obtained, and compared with the acidbase equilibria of silk evaluated from the adsorption of hydrochloric acid.

\section{THEORY}

\subsection{Gilbert-Rideal and Peters-Speakman Theories}

In order to clarify the issues of the GilbertRideal and Peters-Speakman theories, we shall show their derivations again.

The adsorption of hydrogen ions on fibers is treated by the same expression in both theories. The hydrogen ions in the fiber-aqueous solution system exist in three different states as shown in Fig. 1; the hydrogen ions combined with the sites provided by acidic dissociative groups of the fiber $\left(\mathrm{H}_{\mathrm{f}}\right)$, those existing in water contained within the fiber phase $\left(\mathrm{H}_{\mathrm{i}}\right)$, and those dissolved in the external solution $\left(\mathrm{H}_{\mathrm{s}}\right)$. Assuming that the whole of the fiber is regarded as an equipotential volume, the 
equilibrium between $H_{f}$ and $H_{i}$ can be written as follows:

$$
-\Delta \mu_{\mathrm{H}}^{\circ}=R T \ln \frac{\theta_{\mathrm{H}}}{1-\theta_{\mathrm{H}}}-R T \ln a_{\mathrm{H}}^{i},
$$

where $\Delta \mu_{\mathrm{H}}^{\circ}$ is the "intrinsic" affinity of hydrogen ion for the fiber, $\theta_{\mathrm{H}}$ is the fraction of the sites occupied by $\mathrm{H}_{\mathrm{f}}$, and $a_{\mathrm{H}}{ }^{\mathrm{i}}$ is the activity of $\mathrm{H}_{\mathrm{i}}$.

In the equilibrium between $H_{i}$ and $H_{s}$, the electrical potential between the internal and external solutions must be taken into consideration. If $\phi$ is the potential given by the adsorption of hydrogen ion, the electrochemical potential of $\mathrm{H}_{\mathrm{i}}$, $\bar{\mu}_{i}$, may be written by

$$
\bar{\mu}_{\mathrm{i}}=\mu_{\mathrm{i}}^{\mathrm{c}}+R T \ln a_{\mathrm{H}}^{\mathrm{i}}+F \phi,
$$

where $F$ is the Faraday constant. In the external solution,

$$
\bar{\mu}_{\mathrm{s}}=\mu_{\mathrm{s}}^{\circ}+R T \ln a_{\mathrm{H}}^{\mathrm{s}},
$$

where $\bar{\mu}_{\mathrm{s}}$ and $a_{\mathrm{H}}^{\mathrm{s}}$ are the electrochemical potential and the activity of $\mathrm{H}_{\mathrm{s}}$, respectively. At equilibrium these two electrochemical potentials must be equal, and if the internal solution has the same properties as the external solution,

$$
\mu_{i}^{\circ}=\mu_{\mathrm{g}}^{\circ}
$$

so that

$$
R T \ln {a_{\mathrm{H}}}^{\prime}=R T \ln {a_{\mathrm{H}}}^{\mathrm{s}}-F \phi
$$

Substitution of eq. (5) in eq. (1) gives

$$
-\Delta \mu_{\mathrm{H}}^{\circ}=R T \ln \frac{\theta_{\mathrm{H}}}{1-\theta_{\mathrm{H}}}-R T \ln a_{\mathrm{H}}^{\mathrm{s}}+F \phi .
$$

On the other hand, the adsorption of anions has been differently treated according to the standpoints of investigators. In the Gilbert-Rideal theory, the adsorption of anions was treated as the same process as that of hydrogen ions, i.e.,

$$
-\Delta \mu_{\mathrm{x}}^{\circ}=R T \ln \frac{\theta_{\mathrm{x}}}{1-\theta_{\mathrm{x}}}-R T \ln a_{\mathrm{x}}-F \phi
$$

where the symbol $X$ represents an anion. In the Peters-Speakman theory, since no combination of anions with the fiber was assumed, the activity of anions inside the fiber was represented by the concentration, $\left[X_{i}\right]$, to a first approximation. Then the moles of $X_{i}$ are approximately equal to the moles of $\mathrm{H}_{\mathrm{f}}$, so that

$$
-\Delta \mu_{\mathrm{x}}^{\circ}=R T \ln \frac{\left[\mathrm{H}_{\mathrm{f}}\right]}{V}-R T \ln a_{\mathrm{x}}^{\mathrm{s}}-F \phi,
$$

where $V$ is the volume of the internal solution and $\left[\mathrm{H}_{\mathrm{f}}\right]$ is the moles of $\mathrm{H}_{f}$ per weight of the dry fiber. In eqs. (7) and (8), it should be noted that the electrical work is reversed in sign in considering the adsorption of ions of opposite sign.

Finally, the adsorption expression of the GilbertRideal theory is obtained by adding eq. (6) to eq. (7),

$-\left(\Delta \mu_{\mathrm{H}}^{\circ}+\Delta \mu_{\mathrm{X}}^{\circ}\right)=2 R T \ln \frac{\theta_{\mathrm{H}}}{1-\theta_{\mathrm{H}}}-2 R T \ln {a_{\mathrm{H}}}^{\mathrm{s}}$.

While, the expression of the Peters-Speakman theory is derived by adding eq. (6) to eq. (8). Thus,

$$
-\Delta \mu_{\mathrm{H}}^{\circ}=R T \ln \frac{\theta_{\mathrm{H}}}{1-\theta_{\mathrm{H}}} \frac{\left[\mathrm{H}_{\mathrm{f}}\right]}{V}-2 R T \ln a_{\mathrm{H}}^{\mathrm{s}},
$$

$\Delta \mu_{\mathrm{x}}^{\circ}$ being put equal to zero since it is assumed that no combination of anions occurs.

\section{2 "Apparent" and "Intrinsic" Affinities of Hydrogen Ion}

The theories described above include the three important assumptions: First, the whole of the fiber containing the internal solution is regarded as an equipotential (eq. (1)). Second, the internal solution has the same properties as those of the external solution (eqs. (4) and (5)). Finally, the electrical potential produced by the adsorption of hydrogen ions is entirely counteracted by the opposite potential of adsorbed anions because the moles of adsorbed hydrogen ions and anions must be the same from the electrical neutrality (eqs. (9) and (10)).

The first assumption may be considered to be a reasonable approximation for a complicated potential in the fiber phase. The second one is not realistic because the absorbed water is different from the bulk water. Hence, $\mu_{i}^{\circ}$ is not equal to $\mu_{\mathrm{s}}^{\circ}$, so that

$$
-\left(\mu_{\mathrm{i}}^{\circ}-\mu_{\mathrm{s}}^{\circ}\right) \equiv-\Delta \mu_{\mathrm{D}}^{\circ}=R T \ln \frac{a_{\mathrm{H}}^{\mathrm{i}}}{a_{\mathrm{H}}^{\mathrm{s}}}+F \psi .
$$

Addition of eq. (1) to eq. (11) gives

$$
-\left(\Delta \mu_{\mathrm{H}}^{\circ}+\Delta \mu_{\mathrm{D}}^{\circ}\right)=R T \ln \frac{\theta_{\mathrm{H}}}{1-\theta_{\mathrm{H}}}-R T \ln a_{\mathrm{H}}^{\mathrm{s}}+F \phi .
$$


Fiber Phose: Internal solution Externol solution (f) Phase; (1) Phose; (s)

(0)

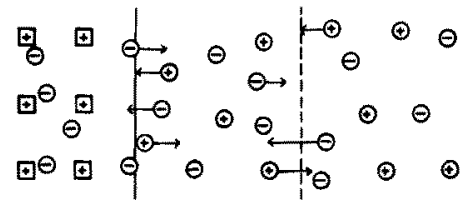

(b)

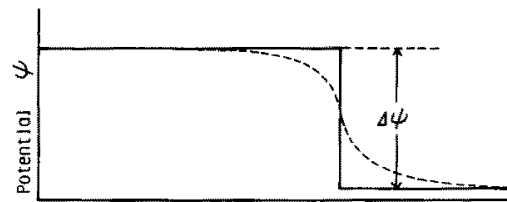

Fig. 1. Schematic diagram of distribution of hydrogen and chloride ions and electrical potential: (a) hydrogen ions fixed with the fiber (⿴), chloride ions as counterfons $(\Theta)$, and free hydrogen ions as coions $(\oplus)$; (b) hypothetical potential (-) and potential function of Donnan theory ${ }^{13)} \cdot(-\cdots--)$.

Since the right-hand side of eq. (12) is identical with that of eq. (6), $\Delta \mu_{\mathrm{i}}^{\circ}$ is no more than the "apparent" affinity, $\Delta \mu_{\mathrm{A}}^{\circ}$, in the case of $\mu_{\mathrm{i}}^{\circ} \neq \mu_{\mathrm{s}}^{\circ}$. Thus,

$$
-\Delta \mu_{\mathrm{A}}^{\circ}=-\left(\Delta \mu_{\mathrm{H}}^{\circ}+\Delta \mu_{\mathrm{D}}^{\circ}\right)
$$

The last assumption is not acceptable under the current electrochemical theories. The electrical potential given by the adsorption of hydrogen ions on fibers $(+\phi$ in eq. (6)) does not precisely counteract the potential given by the adsorption of anions since the affinities of both ions are different. Then, the adsorption of both ions in equilibrium give rise to an electrical potential difference, $\Delta \phi$, between the internal and external solutions as schematically shown in Fig. 1.

From this point of view, the affinities of hydrogen ion can be expressed as follows:

$$
\begin{aligned}
& -\frac{\Delta \mu_{\mathrm{A}}^{\circ}+F \Delta \phi}{2.3 R T}=\mathrm{p} K_{\mathrm{a}}=\log \frac{\theta_{\mathrm{H}}}{1-\theta_{\mathrm{H}}}-\log a_{\mathrm{H}}^{\mathrm{s}} \\
& -\frac{\Delta \mu_{\mathrm{H}}^{\circ}}{2.3 R T}=\mathrm{p} K_{\mathrm{o}}=\log \frac{\theta_{\mathrm{H}}}{1-\theta_{\mathrm{H}}}-\log a_{\mathrm{H}}^{\mathrm{i}} \\
& -\frac{\Delta \mu_{\mathrm{D}}^{\circ}+F \Delta \phi}{2.3 R T}=\mathrm{p} K_{\mathrm{d}}=\log \frac{a_{\mathrm{H}}^{\mathrm{i}}}{a_{\mathrm{H}}^{\mathrm{s}}},
\end{aligned}
$$

where $K_{\mathrm{a}}$ and $K_{\mathrm{o}}$ are the "apparent" and "intrinsic" dissociation constants of the dissociative groups of the fiber respectively, and $K_{\mathrm{d}}$ is the "apparent" distribution constant including the contribution of the electrical potential. The rela. tion between $K_{\mathrm{a}}, K_{\mathrm{o}}$, and $K_{\mathrm{d}}$ is as follows.

$$
\mathrm{p} K_{\mathrm{a}}=\mathrm{p} K_{\mathrm{o}}+\mathrm{p} K_{\mathrm{d}}
$$

The parameter $\left(\Delta \mu_{\mathrm{A}}^{\circ}+F \Delta \phi\right)$ is identical with the Gilbert-Rideal affinity of acids, $\left(\Delta \mu_{\mathrm{H}}{ }^{\circ}+\Delta \mu_{\mathrm{X}}{ }^{\circ}\right) / 2$, which was assumed to be constant. However, the parameter may be dependent on $\mathrm{pH}$ value of the external solution if the $\Delta \phi$ is changed by the adsorption of hydrochloric acids.

\section{EXPERIMENTAL}

\subsection{Preparation of DNS-Silk Conjugate}

Silk fiber used in this work was obtained from raw silk (supplied from Gunze Co., Ltd.) according to the procedure of $\mathrm{Kato}^{3}$. For the preparation of DNS-silk conjugate, samples ( $c a .300 \mathrm{mg}$ ) of the silk were soaked successively in $500 \mathrm{ml}$ of $0.5 \mathrm{~g} /$ 5 - dimethylamino - 1 - naphthalenesulfonylchloride (Tokyo Chemical Co., Ltd.) in acetone for $24 \mathrm{hr}$, $0.1 \mathrm{M} \mathrm{Na}_{2} \mathrm{HPO}_{4}$ solution for $24 \mathrm{hr}$, and $0.01 \mathrm{M}$ acetic acid solution for $6 \mathrm{hr}$. After the conjugation, the samples were soaked in ethanol/water $(80: 20)$ mixture at $55^{\circ} \mathrm{C}$ to remove the hydrolyzed DNS from the samples. The extraction was performed in the mixtures renewed every $24 \mathrm{hr}$ until the fluorescence of free DNS was not detected in the mixture.

\subsection{Measurement of DNS Amount in Silk}

The amounts of DNS conjugated to the silk were calculated from UV measurements of the aqueous $\mathrm{LiBr}$ solutions using extinction coefficient of 3.36 $\times 10^{6} \mathrm{M}^{-1} \mathrm{~cm}^{-1}$ at $340 \mathrm{~nm}^{6}$. The contents of DNS in the fiber were found to be less than $1.0 \times$ $10^{-5} \mathrm{~mol} / \mathrm{g}$ of dry fiber.

\subsection{Determination of $\mathbf{p} K_{\mathrm{a}}$ Values of DNS-Silk Conjugate}

Yarn of DNS-silk fiber was coiled round a film holder plate described in the previous work ${ }^{1)}$ so as not to be overlapped. The coiled fiber did not loosen or slip down during the $\mathrm{pH}$ measurements. The holder fixing the silk was completely inserted in $1 \mathrm{~cm}$ length cell for the fluorescence measurement. The silk held in the cell was soaked in water or $0.1 \mathrm{M} \mathrm{NaCl}$ solution containing an appropriate amount of hydrochloric acid. After the shaking for $12 \mathrm{hr}$ the $\mathrm{pH}$ of the solution and the emission spectra were measured at $25.0^{\circ} \mathrm{C}$ in the same manner as in the previous experiment ${ }^{1)}$. The 
reflection spectra of the unconjugated silk were measured at various $\mathrm{pH}$ values to obtain the net fluorescence of DNS-silk conjugate. The $\mathrm{p} K_{\mathrm{a}}$ values were calculated from the $\mathrm{pH}$ values and the fluorescence according to the procedure described previously ${ }^{1)}$.

In order to evaluate the $\mathrm{p} K_{0}$ value of DNS, the fluorescence of DNS-glycine conjugate $\left(5.0 \times 10^{-4}\right.$ M) was measured in aqueous solutions. As the $\mathrm{p} K$ value of DNS-glycine was $3.95 \pm 0.05$ in water and $3.93 \pm 0.05$ in $0.1 \mathrm{M} \mathrm{NaCl}$, the $\mathrm{p} K_{\mathrm{o}}$ value of DNS was estimated to be 3.9 .

\subsection{Determination of $\mathrm{p} K_{\mathrm{a}}$ Values of the Dissoci- ative Groups of Silk}

The amounts of hydrochloric acid adsorbed on the unconjugated silk fiber in water and $0.1 \mathrm{M}$ $\mathrm{NaCl}$ at $25.0^{\circ} \mathrm{C}$ were determined according to the direction of $\mathrm{Kato}^{3}$. The amounts in $\mathrm{mol} / \mathrm{g}$ of dry fiber gave the $\theta_{\mathrm{H}}$ values from the saturation value of adsorption (See results.). Then, $\mathrm{p} K_{\mathrm{a}}$ values were calculated by eq. (14).

In the case of $0.1 \mathrm{M} \mathrm{NaCl}$ solution, concentrations of chloride ion were measured before and after soaking the silk and found to be the same within the experimental error.

\subsection{Apparatus}

Absorption spectra and fluorescence spectra were recorded with a Hitachi spectrophotometer 124 and a Hitachi Perkin-Elmer MPF 2A fluorescence spectrophotometer, respectively. The $\mathrm{pH}$ was measured with a Hitachi-Horiba F-7AD pH meter and a $6326-05 \mathrm{C}$ combination electrode. The concentration of chloride ion was determined with an Orion $601 \mathrm{~A} \mathrm{mV} / \mathrm{pH}$ meter equipped with a 94-17 chloride electrode.

\section{RESULTS AND DISCUSSION}

\subsection{Variation of $\mathrm{p} K_{\mathrm{a}}$ of DNS-Silk Conjugate}

The $\mathrm{p} K_{\mathrm{a}}$ values of DNS conjugated to silk in water and $0.1 \mathrm{M} \mathrm{NaCl}$ solution are shown as a function of $\mathrm{pH}$ by open circles in Fig. 2(a) and 3(a). In both solutions, the $\mathrm{p} K_{\mathrm{a}}$ values were less than the $\mathrm{p} K_{0}$ value of DNS and decreased linearly with decreasing $\mathrm{pH}$. If the linear relationship is kept up to isoelectric point of silk fiber, $\mathrm{pH} 4^{9}$, the $\mathrm{p} K_{\mathrm{a}}$ value at isoelectric point gives 3.2 in water and 3.3 in $0.1 \mathrm{M} \mathrm{NaCl}$. The difference of these values from the $\mathrm{p} K_{\mathrm{o}}$ value, the $\mathrm{p} K_{\mathrm{d}}$ value, can be attributed only to the $\Delta \mu_{\mathrm{D}}^{\circ}$ term in eq. (16) since $\Delta \psi$ is zero at the isoelectric point. The $\Delta \mu_{D}^{\circ}$ term results from the change of the activity coefficient of hydrogen ion in both phases, which is called "medium effect" It is known that the "medium effect" is attributed mainly to the dielectric constant difference in the solvents.") The dielectric constant of the internal solution could be evaluated from the relation between the fluorescence peak wavelength of DNS and the dielectric constant of the solvent containing DNS as described previously ${ }^{8}$. As shown in Fig. 2(b) and $3(\mathrm{~b})$, the dielectric constants were constant in both aqueous and $0.1 \mathrm{M} \mathrm{NaCl}$ solutions in the range of $\mathrm{pH}$ measured. The $\Delta \mu_{\mathrm{p}}^{\circ}$ term can be then taken as constant in such a $\mathrm{pH}$ range, and hence eq. (16) indicates that the change in $\mathrm{p} K_{\mathrm{d}}$ is caused solely by that of $\Delta \psi$. As the $\mathrm{p} K_{\mathrm{o}}$ value is constant in eq. (17), the decrease in $\mathrm{p} K_{\mathrm{a}}$ with decreasing $\mathrm{pH}$ is attributable to the increase of $\Delta \phi$.

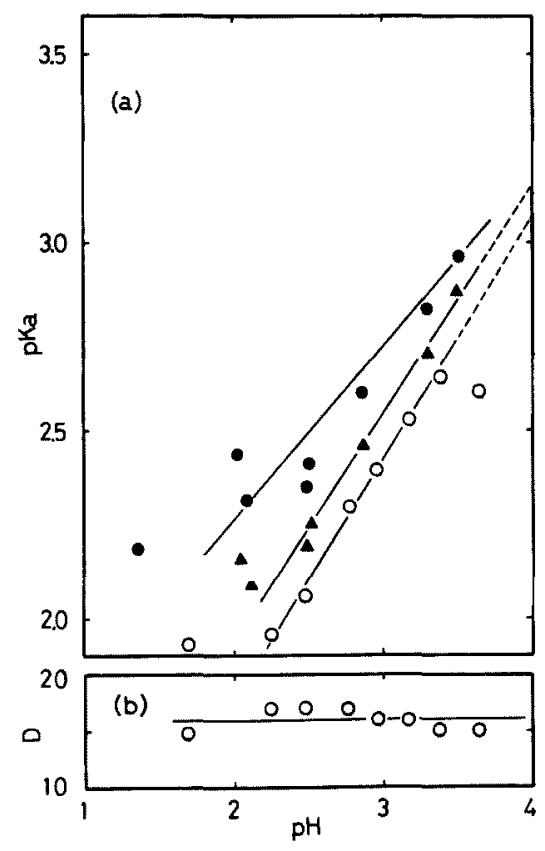

Fig. 2. $\mathrm{p} K_{\mathrm{a}}$ values and dielectric constant $D$ of silk at various $\mathrm{pH}$ values in the absence of salt: (a) $\mathrm{p} K_{\mathrm{a}}$ values obtained in DNS conjugate (O), estimated from the adsorption of $\mathrm{HCl}$ by silk (-), and corrected with activity coefficient of hydrogen ions inside silk ( $\mathbf{\Lambda}$ ); (b) dielectric constants $D$ were evaluated from emission peaks at $\mathrm{pH}$ values. 


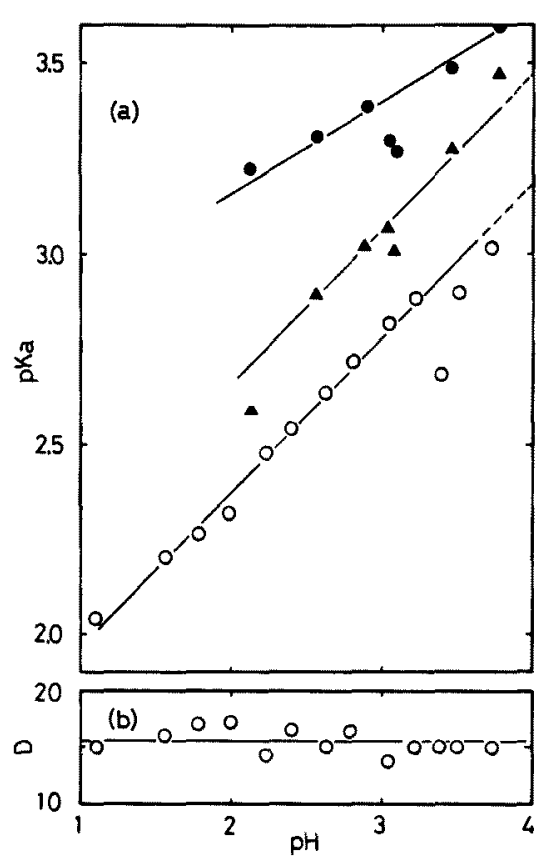

Fig. 3. $\mathrm{p} K_{\mathrm{a}}$ values and dielectric constant $D$ of silk at various $\mathrm{pH}$ values in $0.1 \mathrm{M} \mathrm{NaCl}$ solution: Symbols are the same as in Fig. 2.

According to eqs. (16) and (17), the plots of $\mathrm{p} K_{\mathrm{a}}$ against $\mathrm{pH}$ in Fig. 2(a) and.3(a) are expressed by the following relation:

$$
\mathrm{p} K_{\mathrm{a}}=\mathrm{p} K_{\mathrm{o}}+\frac{-\Delta \mu_{\mathrm{D}}^{\circ}}{2.3 R T}+\frac{-F \Delta \psi}{2.3 R T}
$$

Then, in water,

$$
\mathrm{p} K_{\mathrm{a}}=3.9+(-0.7)+0.7(\mathrm{pH}-4),
$$

and in $0.1 \mathrm{M} \mathrm{NaCl}$ solution,

$$
\mathrm{p} K_{\mathrm{a}}=3.9+(-0.6)+0.4(\mathrm{pH}-4) \text {. }
$$

From the relations, (18) and (19), it is found that the values of the $\left(\Delta \mu_{\mathrm{D}}{ }^{\circ} / 2.3 \mathrm{RT}\right)$ for both solutions are in fair agreement but that the magnitude of the $(F \Delta \phi / 2.3 \mathrm{RT})$ term is larger in water than in $0.1 \mathrm{M} \mathrm{NaCl}$. The result suggests that the salt exert a strong influence on the electrical potential but a vanishing one on the medium of the internal solution.

\subsection{Comparison of $\mathrm{p} K_{\mathrm{a}}$ Values for DNS Conju- gate and Silk}

As the adsorption of acids on fiber is essentially produced by the protonation to dissociative groups of the fiber, the $\mathrm{p} K_{\mathrm{a}}$ value for the fiber as well as the affinity for the fiber can be evaluated by the adsorption. The affinity of hydrochloric acid for silk was evaluated by Kato ${ }^{3)}$ based on the GilbertRideal and Peters-Speakman theories. Although the affinities in both theories must be constant, the reported affinities determined at various $\mathrm{pH}$ values tend to increase with increasing $\mathrm{pH}$, which shows that the affinities are reinterpreted in terms of eq. (14). The $\mathrm{p} K_{\mathrm{a}}$ values calculated from Kato's data by eq. (14) are shown as a function of $\mathrm{pH}$ in Fig. 4. Fair linear relationships are found between $\mathrm{p} K_{\mathrm{a}}$ and $\mathrm{pH}$.

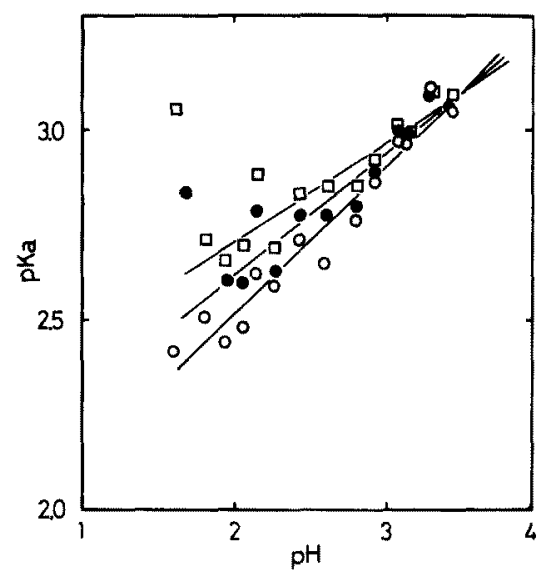

Fig. 4. The variation of $\mathrm{p} K_{\mathrm{a}}$ values of silk evaluated from the data of $\mathrm{Kato}^{3)}$; at $7^{\circ} \mathrm{C}(\square)$, $30^{\circ} \mathrm{C}(\bullet)$, and $50^{\circ} \mathrm{C}(\mathrm{O})$.

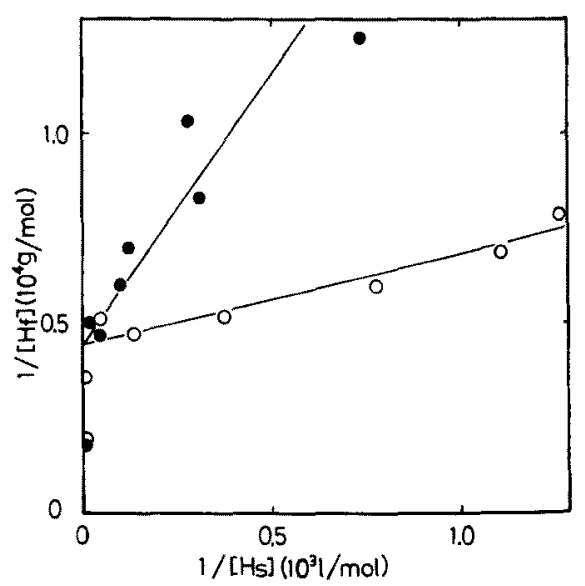

Fig. 5. Reciprocal plots of adsorption of $\mathrm{HCl}$ on silk at $25^{\circ} \mathrm{C}$ in the absence of salt (-) and in $0.1 \mathrm{M} \mathrm{NaCl}$ solution (O). 
The adsorption of hydrochloric acids on the silk prepared in this work was measured at $25.0^{\circ} \mathrm{C}$ according to the procedure of Kato ${ }^{3)}$. Both saturation values of the adsorption in water and $0.1 \mathrm{M}$ $\mathrm{NaCl}$ were obtained as $22.8 \times 10^{-5} \mathrm{~mol} / \mathrm{g}$ of dry fiber by extrapolation of Langmuir's plots in Fig. 5 . This value is slightly larger than that reported by Kato. This might be attributed to the difference between silk samples employed. The $\mathrm{p} K_{\mathrm{a}}$ values in water and $0.1 \mathrm{M} \mathrm{NaCl}$ are shown by filled circles in Fig. 2(a) and 3(a). The relation between $\mathrm{p} K_{\mathrm{a}}$ and $\mathrm{pH}$ is similar to those calculated from Kato's data.

The amount of DNS conjugated to silk, $c a .1 .0$ $\times 10^{-5} \mathrm{~mol} / \mathrm{g}$ of dry fiber, was appreciably smaller than the conterit of basic amino acid residues in silk $\left(10-15 \times 10^{-5} \mathrm{~mol} / \mathrm{g} \text { of dry fiber }\right)^{10)}$. It seems quite reasonable to consider that the acid-base equilibria of the dissociative groups of the fiber are not influenced by the presence of DNS. Then, the changes of $\mathrm{p} K_{\mathrm{a}}$ against $\mathrm{pH}$ must be the same in both evaluations by the adsorption of hydrochloric acids and by the protonation of DNS conjugate. In Fig. 2(a) and 3(a), however, the slopes of $\mathrm{p} K_{\mathrm{a}}$ estimated from the adsorption (filled circles) are smaller than those of $\mathrm{p} K_{\mathrm{a}}$ obtained from the protonation of DNS conjugate (open circles).

Since the dielectric constants inside the silk fibers are remarkably smaller than that of solvent water (Fig. 2(b) and 3(b)), the internal solution can be regarded as an apolar solvent. Under such circumstances, hydrochloric acid might not behave as a strong acid. The medium effect on a strong acid, trichloroacetic acid, was reported by Budevsky, et al. ${ }^{11)}$ Their results indicate that the activity coefficient of hydrogen ion, $r_{H}$, in ethanol (dielectric constant 25 ) at $25.0^{\circ} \mathrm{C}$ is $0.76-0.81$ in the acid concentration range $0.25-7.86 \mathrm{mM}$.

As a rough approximation, hydrochloric acids adsorbed on the fiber are assumed to have the same activity coefficient of 0.8 as trichloroacetic acid in ethanol. If the amounts of free hydrogen ions in the internal solution be neglected compared with the amounts of hydrogen ions fixed with the fiber, the fraction of the occupied sites for hydrogen ions is represented by $\theta_{\mathrm{H}} \gamma_{\mathrm{H}}$ Accordingly, eq. (14) can be rewritten as follows:

$$
\mathrm{p} K_{\mathrm{a}}=\log \frac{\theta_{\mathrm{H}} \gamma_{\mathrm{H}}}{1-\theta_{\mathrm{H}} \gamma_{\mathrm{H}}}+\mathrm{pH}
$$

The $\mathrm{p} K_{\mathrm{a}}$ values in water and $0.1 \mathrm{M} \mathrm{NaCl}$ corrected with eq. (20) are shown by filled triangles in Fig. 2 (a) and 3(a), respectively. These plots are parallel to the $\mathrm{p} K_{\mathrm{a}}$ values obtained from the DNS conjugate. The shift of $\mathrm{p} K_{\mathrm{a}}$ of the silk from that of the DNS conjugate at a $\mathrm{pH}$ value can be attributed to the difference between the $\mathrm{p} K_{\mathrm{o}}$ values of DNS and carboxylate groups in the fiber. It must be remembered that such a difference is also caused by the medium effect on the dissociative groups of the fiber. That is, the charge types of acid (A) and base (B) are $A^{0}$ and $B^{-1}$ in carboxylic acid, and $A^{+1}$ and $B^{0}$ in DNS so that carboxylic acid becomes a more weak acid, while DNS becomes a more strong acid in a solvent with a lower dielectric constant.

These comparisons advocate that hydrochloric acids adsorbed by silk behave not only as hydrogen ion and chloride anion but partly as molecular hydrogen chloride. The molecular acid may contribute to the partition adsorption in the adsorption equilibrium. Along the same lines, the adsorption isotherm of an acid dye is described as a superposition of a Langmuir type and a partition isotherm, which has been reported by Kato. ${ }^{12)}$

\section{ACKNOWLEDGMENT}

Thanks are given to Mr. Yoshihiro Yamazaki for his assistance in the experimental work. The present work was in part supported by a Grant-inAid for Scientific Research from the Ministry of Education, Science, and Culture, and by a grant from the Asahi Glass Foundation for Industrial Technology.

\section{REFERENCES}

1) N. Ikuta, J. Koga, and N. Kuroki; Sen-i Gakkaishi, in press. 36, T-548 (1980).

2) T. Vickerstaff; "The Physical Chemistry of Dyeing", 2nd ed., Oliver and Boyd, London, pp. 351-377 (1954).

3) H. Kato; Sen-i Gakkaishi, 31, T-168 (1975).

4) Lemin; unpublished. (Cited in Vickerstaff, "The Physical Chemistry of Dyeing", 2nd ed., Oliver and Boyd, London, p. 453 (1954).)

5) T. Iijima and M. Sekido; Kogyo Kagaku Zasshi, 63, 70 (1960).

6) B. S. Hartley and V. Massey; Biochim. Biophys. Acta, 21, 58 (1956).

7) E. J. King; "Acid-Base Equilibria", in "The International Encyclopedia of Physical Chem- 
istry and Chemical Physics", ed by E. A. Guggenheim, J. E. Mayer, F. C. Tompkins, Pergaman Press, Oxford, Vol. 4, Chap. 10, pp. 248-279 (1965).

8) I. Abe, J. Koga, and N. Kuroki; Nippon Kagaku Kaishi, 1975, 879.

9) K. Kanamaru and T. Hata; Kogyo Kagaku Zasshi; 47, 544 (1944); ibid., 43, 261 (1940).

10) S. Simizu, N. Fukuda, and J. Kirimura;
"Tanpakushitsu-Kagaku", ed by S. Akabori, S. Mizushima, Kyoritzu-Shuppan, Tokyo, Vol. 5, pp. 333-339 (1957).

11) O. Budevsky and G. Velinov; Trans. Royal Inst. Technol. (Stockholm) Pure and Appl. Chem., 34, 197 (1972).

12) H. Kato; Sen-i Gakkaishi, 35, T-48 (1978).

13) A. Mauro, Biophys. J., 2, 179 (1962).

綟に導入した光学的プローブの酸塩基平衡から 検討した絹による水素イオンの吸着機構

大阪府立大学工学部 幾田信生，野村英作，古賀城一，黒木宣应

絹に結合した光学的プローブ、, 5-ジメチルアミノー1 ーナフタレンスルホニル基の酸塩基平衡を営光測定によ って水および $0.1 \mathrm{M} \mathrm{NaCl}$ 中で検討した。結合したプロー ブのみかけの $\mathrm{p} K$ 值は水溶液中でのプローブ自身のそれ よりあ小さく，また，溶液の $\mathrm{pH}$ が低下するにしたがっ て低下した。この結果は，Gilbert-Rideal 説および Peters-Speakman説において水素イオンの化学ポテン
シャルと䄉維相の電気ポテンシャルを考慮することによ って説明するととができ：。一方，絹に対する水素仏 ンのみかけの親和力を吸着実験から求めた。その親和力 の值とプロープの $\mathrm{p} K$ 值の比较加ら纎維相にある水素1 オンの活量保数は水溶液中のそ机にくらへておよそ80\% に減少しているととを示した。 